\title{
TGF- $\beta$ Inhibits Ang II-Induced MAPK p44/42 Signaling in Vascular Smooth Muscle Cells by Ang II Type 1 Receptor Downregulation
}

\author{
Bernadet D.M. Meijering ${ }^{a}$ b Els A. van der Wouden ${ }^{a}$ Vincent Pelgröm ${ }^{a}$ \\ Robert H. Henning ${ }^{\mathrm{a}}$ Kumar Sharma ${ }^{\mathrm{c}}$ Leo E. Deelman ${ }^{\mathrm{a}}$ \\ a Department of Clinical Pharmacology, Groningen University Institute for Drug Exploration (GUIDE), \\ University Medical Center Groningen, University of Groningen, Groningen, and b Interuniversity Cardiology \\ Institute Netherlands, Utrecht, The Netherlands; ${ }^{C}$ Center for Renal Translational Medicine, University of \\ California at San Diego/VA San Diego Health System, La Jolla, Calif., USA
}

\section{Key Words}

Angiotensin II $\cdot$ ERK $\cdot$ MAPK $\cdot$ TGF- $\beta 1$

\begin{abstract}
Vascular changes in diabetes are characterized by reduced vasoconstriction and vascular remodeling. Previously, we demonstrated that TGF- $\beta 1$ impairs Ang II-induced contraction through reduced calcium mobilization. However, the effect of TGF- $\beta 1$ on Ang II-induced vascular remodeling is unknown. Therefore, we investigated the effect of TGF- $\beta 1$ on Ang II-induced activation of the MAPK p44/42 pathway in cultured rat aortic smooth muscle cells (RASMC). Activation of MAPK p44/42 was determined with a phospho-specific antibody. Angiotensin type 1 receptor $\left(\mathrm{AT}_{1}\right)$ and $\mathrm{AT}_{1} \mathrm{mRNA}$ levels were measured by $\left[{ }^{3} \mathrm{H}\right]$ candesartan-binding and realtime $P C R$, respectively. $A T_{1}$ gene transcription activity was assessed using $\mathrm{AT}_{1}$ promoter-reporter constructs and by a nuclear runoff assay. In TGF- $\beta 1$-pretreated cells, Ang II-induced phosphorylation of MAPK p44/42 was inhibited by 29 and $46 \%$ for $\mathrm{p} 42$ and $\mathrm{p} 44$, respectively, and $\mathrm{AT}_{1}$ density was reduced by $31 \%$. Furthermore, pretreatment with TGF- $\beta 1$ resulted in a $64 \%$ reduction in $\mathrm{AT}_{1}$ mRNA levels and decreased $\mathrm{AT}_{1}$ mRNA transcription rate by $42 \%$. Pretreatment with TGF$\beta 1$ blocked Ang II-induced proliferation of RASMC, while
\end{abstract}

stimulating Ang II-induced upregulation of plasminogen activator inhibitor-1. In conclusion, TGF- $\beta 1$ attenuates Ang IImediated MAPK p44/42 kinase signaling in RASMC through downregulation of $\mathrm{AT}_{1}$ levels, which is mainly caused by the inhibition of transcription of the $\mathrm{AT}_{1}$ gene.

Copyright $\odot 2009$ S. Karger AG, Basel

\section{Introduction}

Vascular alterations are a common feature in patients with diabetes mellitus and consist of abnormal growth, proliferation and migration of cells. In previous studies, we demonstrated that, in early diabetes, transforming growth factor- $\beta 1$ (TGF- $\beta 1$ ) plays an important role in mediating vascular dysfunction in both renal microvascular smooth muscle cells and in aortic smooth muscle cells [1].

One of the prominent vascular changes induced by diabetes and mediated by TGF- $\beta$ is decreased sensitivity of vascular smooth muscle cells (VSMC) to angiotensin II (Ang II). We previously demonstrated that aortic ring contraction in response to Ang II was impaired in diabetic rats, but completely restored to normal in diabetic rats treated with anti-TGF- $\beta 1$ antibodies [1]. Further,

\section{KARGER}

๑ 2009 S. Karger AG, Basel

Fax +41613061234 E-Mail karger@karger.ch www.karger.com www.karger.com/jvr
Dr. Leo E. Deelman

Department of Clinical Pharmacology, University Medical Center Groningen A. Deusinglaan 1

NL-9713AV Groningen (The Netherlands)

Tel. +31 50363 2837, Fax +31 50363 2812, E-Mail l.e.deelman@med.umcg.nl 
VSMC isolated from diabetic rat aorta exhibited impaired Ang II-induced cytosolic calcium signaling, but calcium signaling was normal in VSMC from diabetic rats treated with anti-TGF- $\beta 1$ antibodies in vivo. Further, the effect of diabetes on Ang II-induced calcium signaling was replicated in vitro by administration of TGF- $\beta 1$ and TGF- $\beta 2$ to aortic VSMC in culture. As a possible mechanism, a downregulation of inositol 1,4,5-trisphosphate receptors may be involved in TGF- $\beta$-mediated impairment of Ang II-induced calcium signaling in VSMC [1].

Ang II signaling is mediated through 2 types of receptors, the Ang II type $1\left(\mathrm{AT}_{1}\right)$ and the Ang II type $2\left(\mathrm{AT}_{2}\right)$ receptor. In rodents, 2 distinct isoforms or subtypes of $\mathrm{AT}_{1}$ exist, $\mathrm{AT}_{1 \mathrm{a}}$ and $\mathrm{AT}_{1 \mathrm{~b}}$, with the $\mathrm{AT}_{1 \mathrm{a}}$ being the predominant isoform in VSMC. Ang II-mediated vascular contraction and vascular hypertrophy are mediated mainly through $\mathrm{AT}_{1}[2] . \mathrm{AT}_{1}$ is a $\mathrm{G}$ protein-coupled 7 transmembrane receptor that signals through several signaling pathways. Ang II-induced vascular contraction is mediated mainly through the $\mathrm{PLC} / \mathrm{IP}_{3} /$ calcium route, while Ang II-induced vascular remodeling in diabetes is mediated mainly through the MAPK p44/42 kinase signaling pathway [2]. The involvement of the MAPK p44/42 pathway in vascular remodeling has been demonstrated in several in vitro experiments. Inhibition of the MAPK p44/42 pathway with the MAP kinase (MEK) inhibitor PD98059 completely blocked the growth stimulatory effects of Ang II on VSMC [2]. In addition, the migration of VSMC by Ang II is mediated by the MAPK p44/42 pathway, although the signaling through MAPK p38 appears to be predominant [3].

Besides these effects on proliferation and migration, Ang II-mediated activation of the MAPK p44/42 pathway is involved in the accumulation of extracellular matrix in VSMC. A key mediator in this process is plasminogen activator inhibitor-1 (PAI-1), an inhibitor of the conversion of inactive plasminogen to active plasmin. Plasmin is able to degrade fibrin and extracellular matrix components and therefore PAI-1 contributes to an increased risk of thrombosis and atherosclerotic plaque formation [47]. The expression of PAI-1 can be induced by both Ang II and TGF- $\beta 1$, a process that can be inhibited by the MEK/MAPK p44/42 inhibitor PD98059 [8], although other members of the MAPK signaling may be involved $[9,10]$.

Although we have reported an inhibitory effect of TGF- $\beta 1$ on the Ang II-induced activation of the PLC/IP $/$ calcium route, the effect of TGF- $\beta 1$ on Ang II-induced activation of the MAPK p44/42 signaling pathway in VSMC is still unclear. Therefore, the aim of this study is to investigate the effect of TGF- $\beta 1$ on Ang II-induced activation of the MAPK $\mathrm{p} 44 / 42$ pathway in cultured rat aortic smooth muscle cells (RASMC).

\section{Methods}

\section{Cell Culture}

Primary RASMC were isolated from rat aorta as described earlier [1]. Cells were cultured in DMEM supplemented with $1,000 \mathrm{mg} / \mathrm{l}$ glucose, L-glutamine, $25 \mathrm{~mm}$ HEPES, pyruvate (Gibco BRL), $10 \%$ of bovine calf serum (PAA Laboratories), $100 \mathrm{U} / \mathrm{ml}$ of penicillin and $100 \mu \mathrm{g} / \mathrm{ml}$ streptomycin (Gibco BRL) in a humidified incubator at $37^{\circ} \mathrm{C}$ and $5 \% \mathrm{CO}_{2}$. When cells reached confluence, they were passaged in a 1:3 ratio with trypsin EDTA (Gibco BRL). For all experiments, cells were used between passage 3 and 12 .

\section{Western Blotting}

Cells were washed 3 times using ice-cold phosphate-buffered saline (PBS) and subsequently lysed in $300 \mu$ l of ice-cold RIPA buffer (1\% Igepal ca-630, $1 \%$ SDS, $5 \mathrm{mg} / \mathrm{ml}$ sodium deoxycholate, $1 \mathrm{mM}$ sodium orthovanadate, $10 \mathrm{mM} \beta$-mercapto-ethanol, $40 \mu \mathrm{g} /$ $\mathrm{ml}$ PMSF, $100 \mu \mathrm{g} / \mathrm{ml}$ benzamidine, $500 \mathrm{ng} / \mathrm{ml}$ pepstatin $\mathrm{A}, 500$ $\mathrm{ng} / \mathrm{ml}$ leupeptine and $500 \mathrm{ng} / \mathrm{ml}$ aprotinin in PBS). Protein concentrations were determined using Bio-Rad protein assay. On a 7.5\% SDS-PAGE gel, $10 \mu \mathrm{g}$ of total protein was run, transferred to nitrocellulose and immunoblotted with the MAPK p44/42 (1:1,000 dilution) antibody (sc-7383; Santa-Cruz).

Saturation Binding Assay

RASMC cells were cultured on 24-well cell culture plates. Twenty-four hours before the start of the binding assay, the medium was replaced with fresh medium or fresh medium supplemented with $10 \mathrm{ng} / \mathrm{ml}$ TGF- $\beta 1$. After $24 \mathrm{~h}$ of incubation, cells were washed 3 times with $\mathrm{HBSS}$ at $37^{\circ} \mathrm{C}$. Tritium-labeled candesartan $\left(\left[{ }^{3} \mathrm{H}\right]\right.$ candesartan; $\left.629 \mathrm{~Bq} / \mathrm{mmol}\right)$ was added in a concentration series of $0-10 \mathrm{nM}$ in a volume of $0.5 \mathrm{ml}$ HBSS. Nonspecific binding was determined by adding $1 \mu \mathrm{M}$ cold candesartan. After $1 \mathrm{~h}$ of incubation at $37^{\circ} \mathrm{C}$, plates were placed on ice and the cells were washed 3 times with ice-cold PBS. Cells were subsequently lysed with $500 \mu \mathrm{l}$ of $1 \mathrm{~N} \mathrm{NaOH}$ and total protein content of the lysate was determined using a DC protein assay (Bio-Rad). Total protein content did not differ between groups and the remaining lysate $(490 \mu \mathrm{l})$ was transferred to a scintillation vial containing $3 \mathrm{ml}$ of scintillation fluid. Vials were counted for $3 \mathrm{~min}$ in a scintillation counter. Analysis of the binding data was performed according to the method of Scatchard.

\section{Real-Time PCR}

The expression of $\mathrm{AT}_{1}$ (rat vascular $\mathrm{AT}_{\mathrm{la}}$ ), PAI-1, fibronectin, collagen I and III mRNA in rat aortic smooth cells was analyzed using real-time 2-step quantitative RT-PCR. Quantification was performed with SYBR Green PCR reagents (Molecular Probes Europe) and an ABI PRISM 5700 sequence detection system (Applied Biosystems). A 50- $\mu$ l PCR mixture contained 0.5 U Taq polymerase (Eurogentec), $5 \mu$ l of the supplied reaction buffer, 250 nM dATP, $250 \mathrm{nM}$ dCTP, $250 \mathrm{~nm}$ dGTP, $500 \mathrm{nM}$ dUTP, $2 \mathrm{~mm}$ $\mathrm{MgCl}_{2}, 50 \mathrm{ng}$ cDNA, $500 \mathrm{nM}$ of each gene-specific primer, $1 \mu \mathrm{l}$ of 


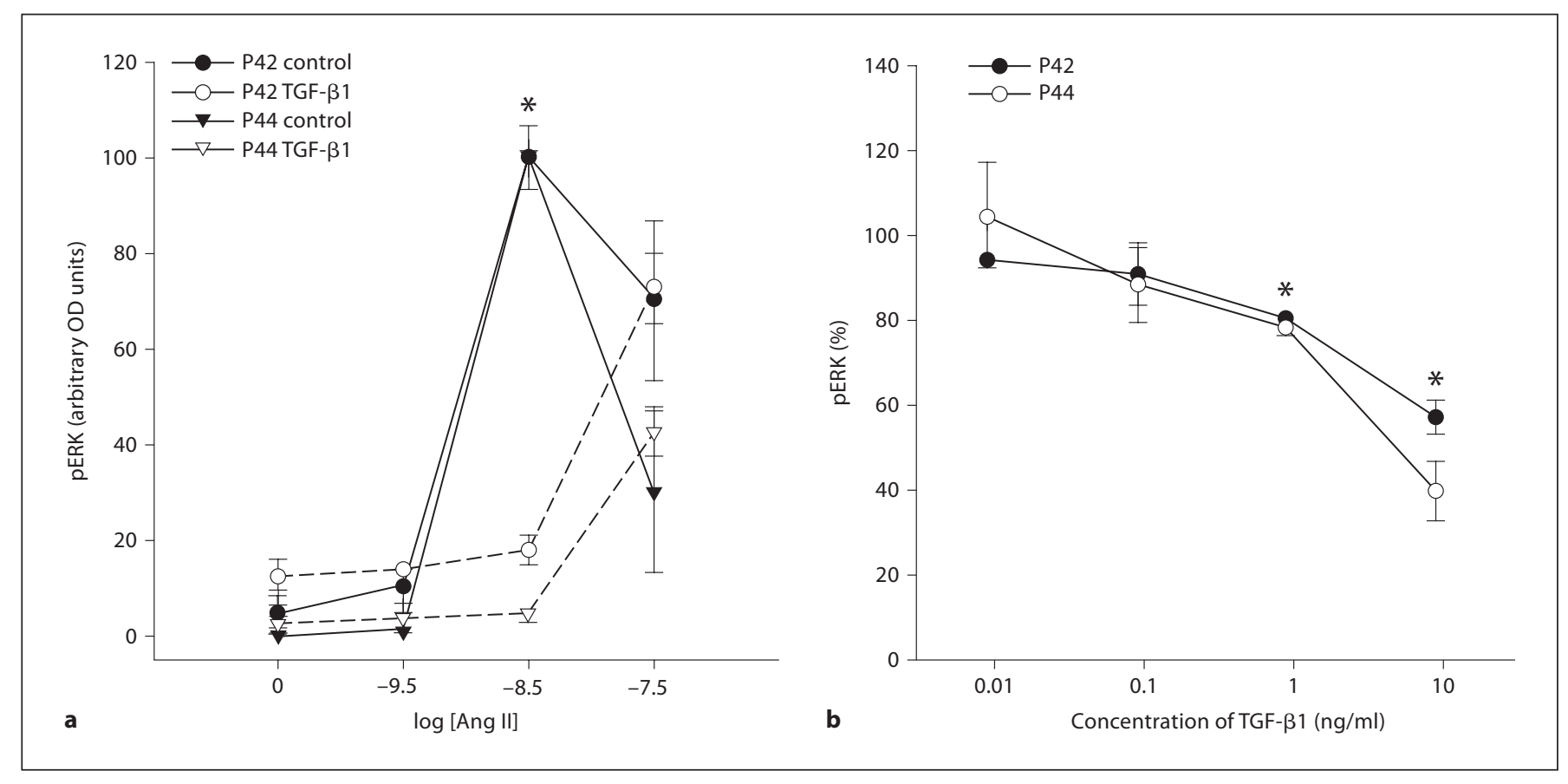

Fig. 1. TGF- $\beta 1$ impairs Ang II-induced MAPK p44/42 signaling. a Incubation of RASMC with TGF- $\beta 1(10 \mathrm{ng} / \mathrm{ml})$ for $24 \mathrm{~h}$ results in a right shift of the dose-response curve to Ang II $(n=3)$. ERK phosphorylation was significantly attenuated in TGF- $\beta 1$-treated cells at $-8.5 \log [$ Ang II] compared to controls. b TGF- $\beta 1$ impairs Ang II-induced MAPK p44/42 signaling in a dose-dependent

$50 \times$ ROX reference dye (Invitrogen) and $1 \mu$ l of $10 \times$ Sybr Green I (Molecular Probes Europe). The PCR profile consisted of 5 min at $95^{\circ} \mathrm{C}$, followed by 40 cycles with heating to $95^{\circ} \mathrm{C}$ for $15 \mathrm{~s}$ and cooling to $60^{\circ} \mathrm{C}$ for $1 \mathrm{~min}$. PCR product specificity and purity was evaluated by gel electrophoresis and by generating a dissociation curve following the manufacturer's recommendations. Sequencespecific PCR primers were purchased from Biolegio. The PCR primers used were as follows: $\mathrm{AT}_{1}$ sense: $5^{\prime}$-CACCAATATCACAGTGTGCGC-3'; AT $_{1}$ antisense: 5'-AGCGTCGAATTCCGAGACTC-3' ( $\mathrm{AT}_{1}$ receptor primer pair is specific for the rat vascular $\mathrm{AT}_{1 \mathrm{a}}$ receptor); PAI-1 sense: 5'-ACCACGGTGAAGCAGGTGGACT-3'; PAI-1 antisense: 5'-AGCACCAGGCGTGTCAGCTCAT-3'; fibronectin sense: $5^{\prime}$-CTGGATGATGGTGGACTGTACT-3'; fibronectin antisense: 5'-TCCTTCTTGCTCCATGTGTCTC-3'; collagen I sense: 5'-TGCCGTGACCTCAAGATGTG-3'; collagen I antisense: 5'-CACAAGCGTGCTGTAGGTGA-3'; collagen III sense: 5'-CACAGCAGTCCAATGTAGAT-3'; collagen III antisense: 5'-TGTAGAAGGCTGTGGACATA-3'.

\section{$A T_{1}$ Promoter Assay}

An 854-bp genomic DNA fragment corresponding to position -828 to +25 of the transcription initiation site of the rat $\mathrm{AT}_{1 \mathrm{a}}$ receptor was cloned in pGL3 basic reporter vector (Promega). RASMC cells were cultured in a 24 -well plate and infected with $2 \mu \mathrm{g}$ of $\mathrm{AT}_{1}$ reporter vector per well. Forty-eight hours after infection, cells were treated with TGF- $\beta 1$ (10 ng/ml). Luciferase activ- manner. RASMC were pretreated for $24 \mathrm{~h}$ with different concentrations of TGF- $\beta 1$. After 5 min of stimulation with Ang II ( $3 \mathrm{nM})$, cells were harvested and phosphorylation of MAPK p44/42 was determined by Western blot $(n=3$, values normalized to untreated cells).

ity was determined using the Luciferase Assay System (Promega).

Real-Time PCR-Based Nuclear Runoff Assay

RASMCs were cultured on $21.5-\mathrm{cm}^{2}$ Nunclon Delta dishes (Nunc). When cells reached confluence, TGF- $\beta 1$ was supplemented to the medium with an end concentration of $10 \mathrm{ng} / \mathrm{ml}$. After $4 \mathrm{~h}$, nuclei were isolated with the nuclei EZ prep isolation kit (Sigma) according to the manufacturer's protocol. Nuclei were dissolved in $250 \mu \mathrm{l}$ of Nuclei EZ storage buffer. Directly after nuclei isolation, $200 \mu \mathrm{l}$ of nuclei suspension were split into 2 aliquots. One hundred microliters of $20 \%$ glycerol, $30 \mathrm{~mm}$ Tris- $\mathrm{HCl}, \mathrm{pH}$ 8.0, $2.5 \mathrm{~mm} \mathrm{MgCl} 2,150 \mathrm{mM} \mathrm{KCl}, 1 \mathrm{~mm}$ DTT and $40 \mathrm{U}$ of RNasin (Promega) were added to each aliquot; $0.5 \mathrm{~mm}$ ribonucleotide mix (rNTPs; New England Biolabs) were added to one aliquot, while no rNTPs were added to the second aliquot. After $30 \mathrm{~min}$ at $30^{\circ} \mathrm{C}$, nuclei were centrifuged at $500 \mathrm{~g}$ for $5 \mathrm{~min}$ at $4^{\circ} \mathrm{C}$ and the pellet was resuspended in $350 \mu \mathrm{l}$ RA1 lysis buffer (Macherey Nachel) with $3.5 \mu$ l of $\beta$-mercapto-ethanol. RNA was subsequently isolated with the nucleospin RNA II kit (Machery Nachel) according to the manufacturer's protocol. $\mathrm{AT}_{1}$ mRNA levels were analyzed by real-time PCR.

\section{Proliferation Assay}

Cells were seeded in 96-well plates (Nunc) at 33\% confluence. The next day, cells were silenced through replacement of the cul- 


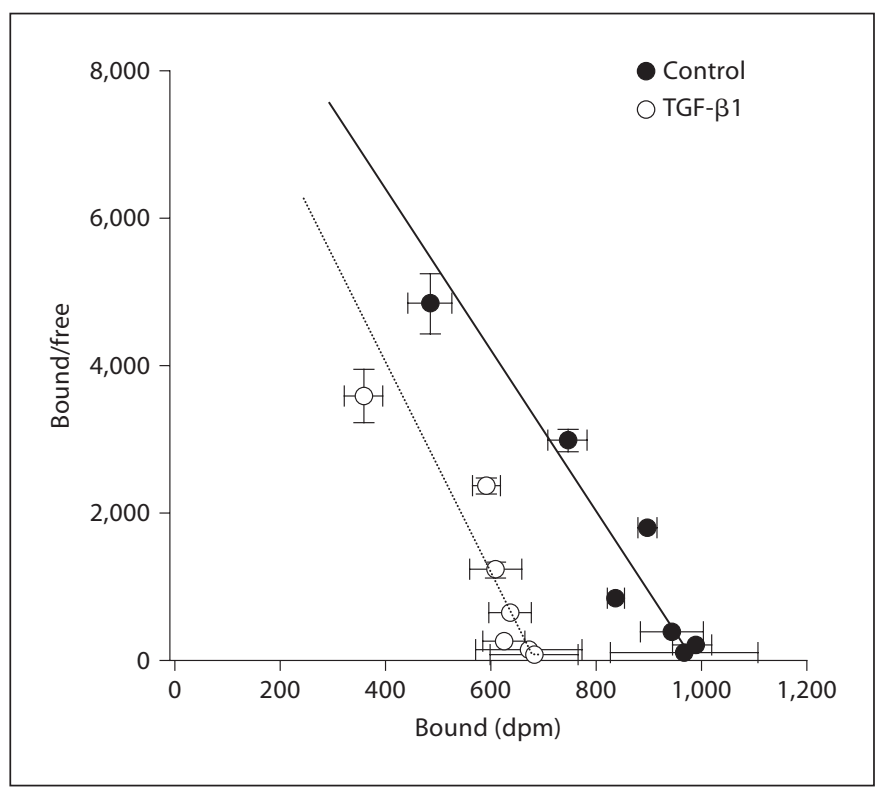

Fig. 2. Scatchard plots of the binding of candesartan. Cells were cultured for $24 \mathrm{~h}$ in the absence and presence of TGF- $\beta 1$ (10 ng/ $\mathrm{ml} ; \mathrm{n}=3$ ). Scatchard analysis of the equilibrium binding studies showed that $B_{\max }$ and equilibrium $K_{d}$ values were $985 \pm 24 \mathrm{dpm}$ and $0.09 \pm 0.01 \mathrm{nM}$ for control cells, respectively. Incubation of cells with TGF- $\beta 1$ significantly decreased $B_{\max }$ to $680 \pm 18 \mathrm{dpm}$, without an effect on $K_{d}(0.07 \pm 0.01 \mathrm{nM})$.

ture medium for culture medium without FCS for $30 \mathrm{~h}$. Subsequently, RASMC were preincubated with $10 \mathrm{ng} / \mathrm{ml}$ TGF- $\beta 1$ for $4 \mathrm{~h}$ prior to Ang II $(0 \mathrm{M}, 3 \mathrm{nM}$ and $1 \mu \mathrm{M})$ stimulation. Twenty hours after Ang II stimulation, proliferation was measured with the $\mathrm{Cy}$ QUANT NF cell proliferation kit (Invitrogen) according to the manufacturer's instructions.

Statistical Analyses

Results are presented as means \pm SEM, unless indicated otherwise. Differences between concentration-response curves were analyzed using repetitive-measurement ANOVA (SigmaStat 1.01; Jandel Scientific) and differences between other variables were tested using Student's t test. Differences were considered significant at $\mathrm{p}<0.05$.

\section{Results}

Stimulation of RASMC with Ang II resulted in a dosedependent increase in phosphorylated MAPK p44 and p42 (fig. 1a). In control cells, maximal levels of phosphorylated p44/42 were observed at $3 \mathrm{nM}$ Ang II. Preincubation of the cells for $24 \mathrm{~h}$ with TGF- $\beta 1(10 \mathrm{ng} / \mathrm{ml})$ resulted in a right shift of the dose-response curve to Ang II (fig. 1a), showing a 50-fold increase in $\mathrm{EC}_{50}$. Preincubation for $24 \mathrm{~h}$ with TGF- $\beta 1(10 \mathrm{ng} / \mathrm{ml})$ did not affect basal phosphorylated MAPK p44/42 levels (fig. 1a; $0 \mathrm{M}$ Ang II).

We next examined the dose dependency of this Ang II-inhibiting effect of TGF- $\beta 1$ on phosphorylation of p42/p44 (fig. 1b). TGF- $\beta 1$ impaired Ang II-induced MAPK p44/42 signaling in a dose-dependent manner with an apparent maximal effect at $10 \mathrm{ng} / \mathrm{ml}$, although higher concentrations were not investigated.

To establish the mechanism of TGF- $\beta 1$-impaired Ang II-induced MAPK p44/42 signaling, we first examined regulation of $\mathrm{AT}_{1}$ by assessing receptor-binding characteristics. Scatchard analysis of the equilibrium-binding studies showed that $B_{\max }$ and equilibrium $K_{d}$ values were $985 \pm 24 \mathrm{dpm}$ and $0.09 \pm 0.01 \mathrm{nM}$ for control cells, respectively (fig. 2). Incubation of cells with TGF- $\beta 1$ significantly decreased $B_{\max }$ to $680 \pm 18 \mathrm{dpm}$, without an effect on $K_{d}(0.07 \pm 0.01 \mathrm{nM})$. These data demonstrate pretreatment with TGF- $\beta 1$ to result in a downregulation of $\mathrm{AT}_{1}$, without changes in receptor affinity for candesar$\tan$.

We next investigated whether the timing of $\mathrm{AT}_{1}$ downregulation matched the timing of the inhibition of Ang II-mediated MAPK p44/42 signaling. RASMC cells were incubated with TGF- $\beta 1(10 \mathrm{ng} / \mathrm{ml})$ at different incubation times and both the levels of specific candesartan binding and phosphorylated p44/p42 were determined (fig. 3). These results demonstrate that the timing of the inhibition of Ang II-mediated MAPK p44/42 signaling parallels the downregulation of $\mathrm{AT}_{1}$.

To establish the mechanism of $\mathrm{AT}_{1}$ downregulation by TGF- $\beta 1$, we determined $\mathrm{AT}_{1}$ mRNA levels in RASMC after incubation with TGF- $\beta 1(10 \mathrm{ng} / \mathrm{ml})$ with different incubations times (fig. $4 \mathrm{a}$ ). Incubation with TGF- $\beta 1$ for $4 \mathrm{~h}$ and longer resulted in decreased $\mathrm{AT}_{1}$ mRNA levels. Next, we investigated whether decreased $\mathrm{AT}_{1}$ mRNA levels by TGF- $\beta 1$ were the result of decreased transcriptional activity of the $\mathrm{AT}_{1}$ gene. Incubation of RASMC with TGF- $\beta 1(10 \mathrm{ng} / \mathrm{ml})$ resulted in decreased $\mathrm{AT}_{1}$ promoter activity after $12 \mathrm{~h}$ of incubation (fig. $4 \mathrm{~b}$ ). These data were further supported by the real-time PCR-based nuclear runoff assay. Thirty minutes of in vitro transcription resulted in a 1.3-fold increase in $\mathrm{AT}_{1}$ mRNA in control cells, whereas 4 -hour treatment of TGF- $\beta 1$ totally blocked transcription of $\mathrm{AT}_{1}$ mRNA (fig. 5a).

Further, we investigated whether the decrease in $\mathrm{AT}_{1}$ mRNA levels by TGF- $\beta 1$ results from changes in $\mathrm{AT}_{1}$ mRNA stability. To this end, all transcription of mRNA was blocked by incubating the cells with actinomycin $\mathrm{D}$ 
Fig. 3. Time course of TGF- $\beta 1$-mediated downregulation of $\mathrm{AT}_{1}$ and inhibition of Ang II-induced MAPK p44/42 activation in RASMC. a Effect of TGF- $\beta 1$ on candesartan binding. Cells were incubated with $10 \mathrm{ng} / \mathrm{ml}$ TGF- $\beta 1$ for $0-24 \mathrm{~h}$, and specific candesartan binding was subsequently determined. b Effect of TGF- $\beta 1$ pretreatment on Ang II-induced MAPK p44/42 phosphorylation. Cells were pretreated with $10 \mathrm{ng} / \mathrm{ml}$ TGF- $\beta 1$ for $0-24 \mathrm{~h}$, and subsequently stimulated with $3 \mathrm{nM}$ Ang II for 5 min. Cells were harvested and pERK phosphorylation was determined by Western blot. Data are expressed as percent of values obtained in cells unexposed to TGF- $\beta 1(n=3)$.
Fig. 4. Time course of TGF- $\beta 1$ effect on $\mathrm{AT}_{1} \mathrm{mRNA}$ and $\mathrm{AT}_{1}$ promoter activity. a Effect of TGF- $\beta 1$ on $\mathrm{AT}_{1}$ mRNA levels. b Effect of TGF- $\beta 1$ on $\mathrm{AT}_{1}$ promoter activity. Data are expressed as percent of values obtained in cells unexposed to TGF- $\beta 1$ $(\mathrm{n}=3) .{ }^{*} \mathrm{p}<0.05$ vs. baseline.
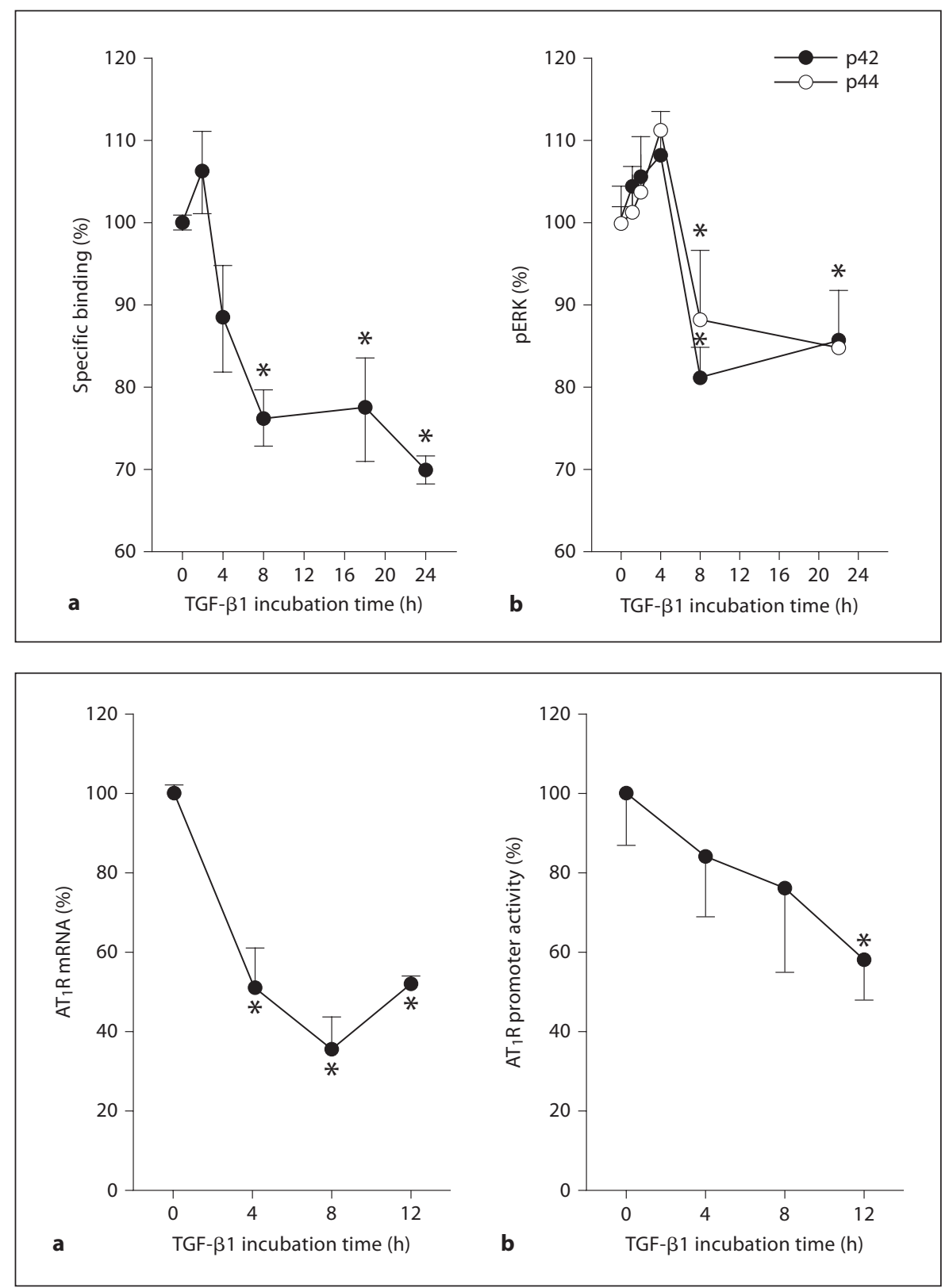

prior to administration of TGF- $\beta 1$. In control cells, the half-life of $\mathrm{AT}_{1}$ mRNA levels was approximately $6 \mathrm{~h}$. Incubation with TGF- $\beta 1$ did not affect the half-life of $\mathrm{AT}_{1}$ mRNA levels (fig. 5b), resulting in identical rates of $\mathrm{AT}_{1}$ mRNA decay for both TGF- $\beta 1$-treated and control cells. Also, identical $\mathrm{AT}_{1}$ mRNA decay rates were observed in untreated and treated cells when TGF- $\beta 1$ was added to the cells $1 \mathrm{~h}$ before the addition of actinomycin $\mathrm{D}$ (data not shown). Therefore, incubation with TGF- $\beta 1$ does not affect the stability of the $\mathrm{AT}_{1}$ mRNA.

Interaction of TGF and Ang II Signaling
To assess the functional implications of the interaction of TGF- $\beta$ and Ang II signaling, the proliferation and expression of profibrotic genes was assessed. Stimulation of RASMC with Ang II resulted in a dose-dependent increase in proliferation in control cells. TGF- $\beta 1(10 \mathrm{ng} / \mathrm{ml})$ itself increased proliferation slightly, however, $4 \mathrm{~h}$ of preincubation of the cells with TGF- $\beta 1(10 \mathrm{ng} / \mathrm{ml})$ completely blocked Ang II-induced proliferation (fig. 6).

Finally, we examined the expression of the fibrotic markers PAI-1, fibronectin, collagen I and collagen III 


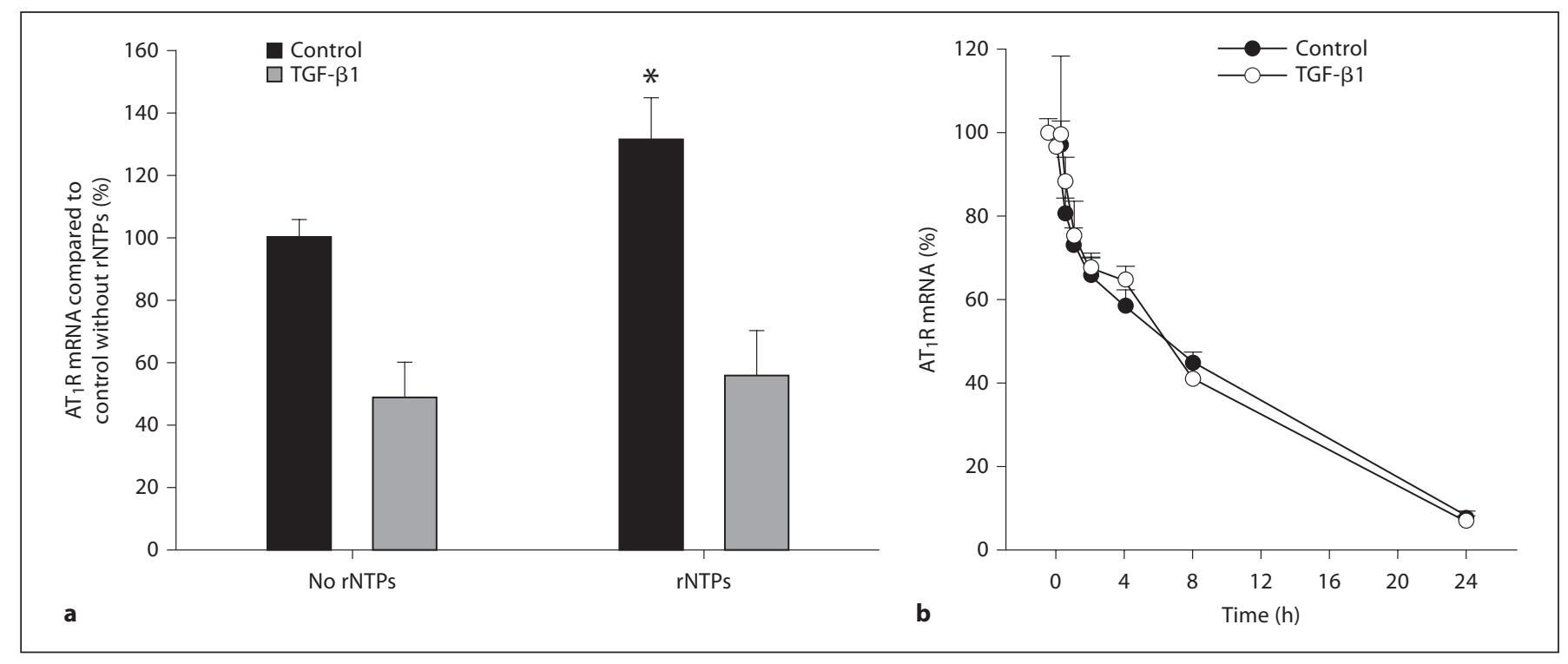

Fig. 5. Effect of TGF- $\beta 1$ on $A_{1}$ gene transcription and $A T_{1}$ mRNA stability. a Nuclear runoff assay on $\mathrm{AT}_{1}$ gene transcription. $\mathrm{AT}_{1}$ gene activity was determined in nuclei from control and TGF- $\beta 1$ pretreated cells $(n=9) .{ }^{*} \mathrm{p}<0.05$ vs. baseline. b AT $\mathrm{mRNA}$ levels were determined after blockage of transcription with actinomycin D in the absence and presence of TGF- $\beta 1(n=3)$. Data are expressed as percent of values obtained in cells unexposed to TGF- $\beta 1$.

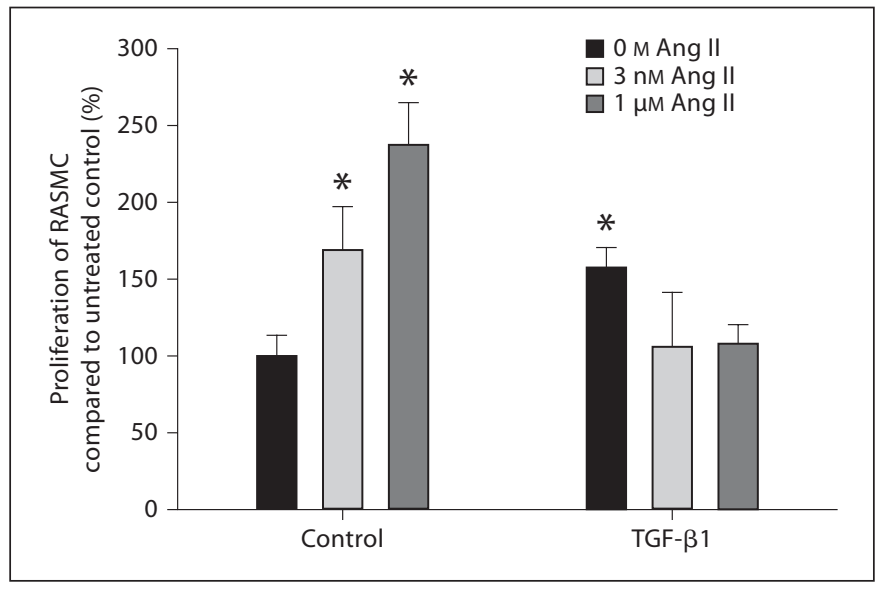

Fig. 6. Effect of TGF- $\beta 1$ pretreatment on Ang II-induced RASMC proliferation. RASMC were pretreated for $4 \mathrm{~h}$ with TGF- $\beta 1$ (10 $\mathrm{ng} / \mathrm{ml}$ ) and subsequently exposed to $0 \mathrm{M}, 3 \mathrm{nM}$ or $1 \mu \mathrm{M}$ Ang II for $24 \mathrm{~h}$. TGF- $\beta 1$ completely blocked Ang II-induced proliferation $(n \geq 9) .{ }^{*} p<0.05$ vs. untreated control. Data are expressed as percent of values obtained in cells unexposed to TGF- $\beta 1$.

(fig. 7). Stimulation of RASMC with Ang II resulted in increased mRNA levels of PAI- 1 and fibronectin. TGF- $\beta 1$ $(10 \mathrm{ng} / \mathrm{ml})$ itself increased PAI-1 expression. Preincubation with TGF- $\beta 1(10 \mathrm{ng} / \mathrm{ml})$ strongly augmented Ang
II-induced PAI-1 expression, indicating a synergistic effect of TGF- $\beta 1$ and Ang II on PAI- 1 expression. The expression of collagen I was decreased after exposure to $3 \mathrm{~nm}$ Ang II. The expression of collagen III was not affected by Ang II or TGF- $\beta 1$.

\section{Discussion}

The present study demonstrates that TGF- $\beta 1$ inhibits the Ang II-induced MAPK p44/42 signaling pathway in cultured RASMC. In TGF- $\beta 1$-pretreated cells, we observed an inhibition of Ang II-induced phosphorylation of MAPK $\mathrm{p} 44 / 42$ and a reduction in $\mathrm{AT}_{1}$ density, without an effect on receptor affinity for candesartan. In addition, $\mathrm{AT}_{1}$ mRNA levels were downregulated and accompanied by a decrease in transcriptional activity of the $\mathrm{AT}_{1}$ gene, without a reduction in $\mathrm{AT}_{1}$ mRNA stability.

The kinetics of the inhibition of Ang II-mediated MAPK p44/42 signaling by TGF- $\beta 1$ closely followed the kinetics of $\mathrm{AT}_{1} \mathrm{mRNA}$ downregulation. In addition, the downregulation of $\mathrm{AT}_{1}$ mRNA levels was accompanied by a reduction in $\mathrm{AT}_{1}$ promoter activity, although the reduction in $\mathrm{AT}_{1}$ promoter activity lagged behind the downregulation of $\mathrm{AT}_{1}$ mRNA levels, probably due to the stability of the luciferase reporter protein. Furthermore, 


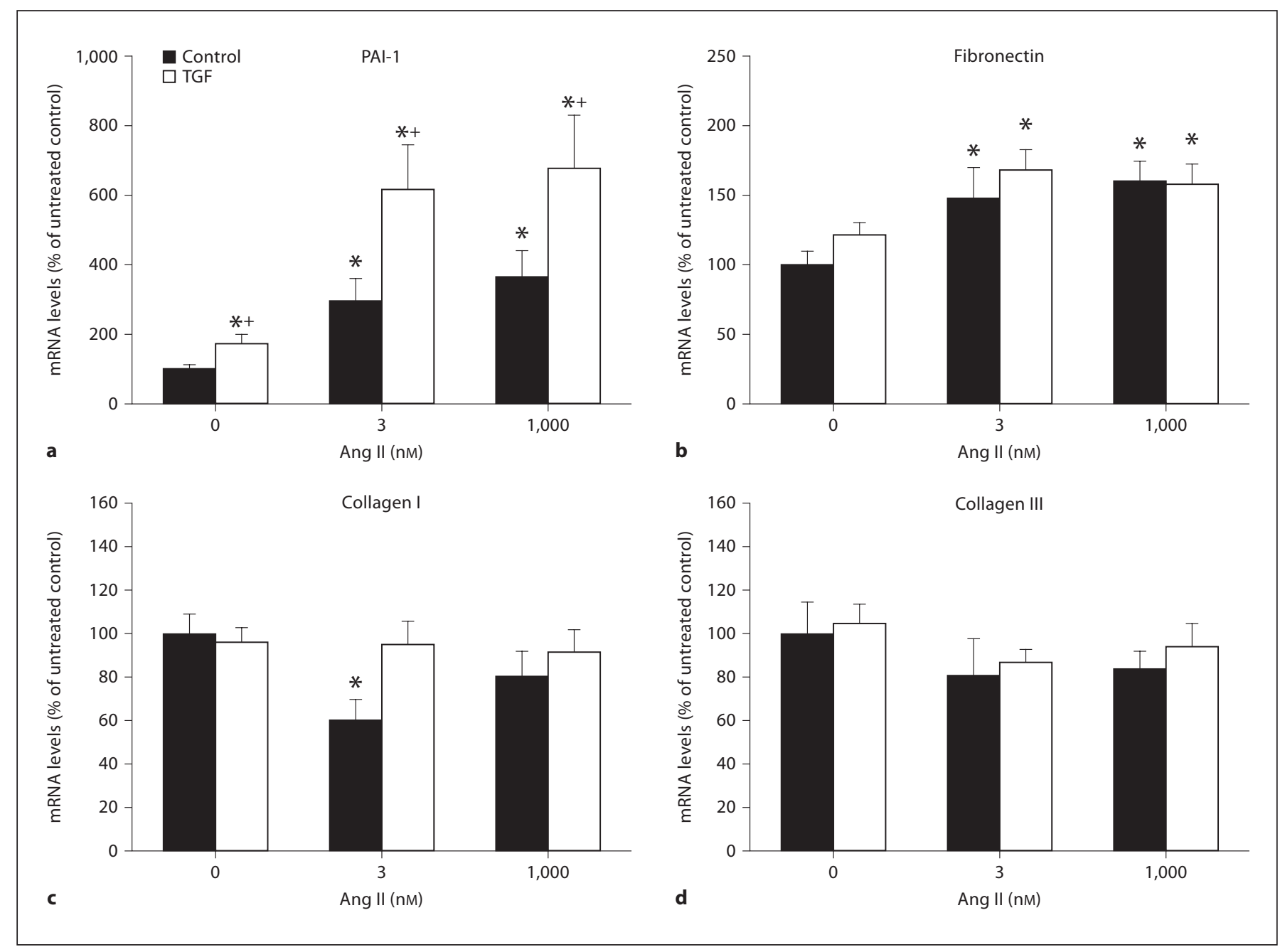

Fig. 7. Effect of TGF- $\beta 1$ pretreatment and Ang II on the expression of fibrotic markers. RASMC were pretreated for $4 \mathrm{~h}$ with TGF- $\beta 1(10 \mathrm{ng} / \mathrm{ml})$ and subsequently exposed to $0 \mathrm{M}, 3 \mathrm{nM}$ or $1 \mu \mathrm{M}$ Ang II for $24 \mathrm{~h}$. a TGF- $\beta 1$ and Ang II act synergistically on the expression of PAI-1. ${ }^{*} \mathrm{p}<0.05$ vs. untreated control; ${ }^{+} \mathrm{p}<0.05$ vs. same concentration Ang II without TGF- $\beta 1$ pretreatment. b Fibronectin expression was increased by Ang II. c Collagen I expression was reduced by 3 nM Ang II. d Collagen III expression was not affected. Data are expressed as percent of values obtained in cells unexposed to TGF- $\beta 1$. the nuclear runoff assay demonstrated that pretreatment with TGF- $\beta 1$ for $4 \mathrm{~h}$ resulted in decreased $\mathrm{AT}_{1}$ mRNA levels and that $\mathrm{AT}_{1}$ gene transcription had halted. As the downregulation of $\mathrm{AT}_{1}$ mRNA levels by TGF- $\beta 1$ did not involve changes in the stability of $\mathrm{AT}_{1} \mathrm{mRNA}$, we conclude that the downregulation of $\mathrm{AT}_{1}$ mRNA by TGF- $\beta 1$ is the result of decreased transcription of the $\mathrm{AT}_{1}$ gene.

Downregulation of $\mathrm{AT}_{1}$ levels has been described previously in TGF- $\beta 1$-treated primary renal proximal tubule cells [11]. Moreover, decreased transcriptional activity of the $\mathrm{AT}_{1}$ promoter by TGF- $\beta$ appears to be a general mechanism for downregulation of $\mathrm{AT}_{1}$ levels in multiple tissues in experimental diabetes[11, 12]. Indeed, decreased levels of $\mathrm{AT}_{1}$ in VSMC exposed to high glucose was already reported in 1992 [12], although the involvement of TGF- $\beta 1$ and its effects on MAPK p44/42 signaling has not been demonstrated before. In contrast to our findings, transcriptional upregulation of human $\mathrm{AT}_{1}$ by TGF- $\beta 1$ has recently been reported in human lung fibroblasts [13]. However, VSMC contain a specific set of transcription factors [14] and therefore the difference in $\mathrm{AT}_{1}$ regulation may arise from cell type-specific gene regulation. Furthermore, in rodents, 2 subtypes of the $\mathrm{AT}_{1}$ receptor exist, while in humans only a single $\mathrm{AT}_{1}$ subtype 
is present. The promoters of the human $\mathrm{AT}_{1}$ and rat vascular $\mathrm{AT}_{1 \mathrm{a}}$ genes differ considerably and may explain the difference in TGF- $\beta 1$-mediated $\mathrm{AT}_{1}$ regulation in human fibroblasts and rat VSMC.

The decreased transcription of the $\mathrm{AT}_{1}$ gene resulted in a reduction in the number of binding sites for the specific $\mathrm{AT}_{1}$ blocker candesartan, indicating a reduction in the number of $\mathrm{AT}_{1}$ receptors on the plasma membrane of RASMC pretreated with TGF- $\beta 1$. Previously, it has been demonstrated that the specific downregulation of $\mathrm{AT}_{1}$ mRNA levels using siRNA against $\mathrm{AT}_{1}$ results in decreased $\mathrm{AT}_{1}$ receptor levels and inhibition of MAPK p44/42 signaling [15]. We therefore conclude that the inhibition of Ang II-induced MAPK p44/42 signaling in TGF- $\beta 1$-pretreated RASMC is most likely caused by decreased gene transcription of the $\mathrm{AT}_{1}$ gene and decreased $\mathrm{AT}_{1}$ receptor levels. It is, however, unclear how the observed moderate decrease in $\mathrm{AT}_{1}$ receptor levels could result in an increase in the $\mathrm{EC}_{50}$ of Ang II by a factor of 50 . Possibly, posttranslational modifications to the $\mathrm{AT}_{1}$ could alter the affinity of the $\mathrm{AT}_{1}$ for Ang II, as has been demonstrated previously [16]. However, we did not observe a change in the affinity of the $\mathrm{AT}_{1}$ for the competitive antagonist candesartan after TGF- $\beta 1$ pretreatment. It is therefore unlikely that pretreatment with TGF- $\beta 1$ results in conformational changes to the Ang II-binding site of the $\mathrm{AT}_{1}$. Alternatively, inhibition of downstream coupling of the $\mathrm{AT}_{1}$ to $\mathrm{G}$ proteins and second-messenger systems may be additional mechanisms for inhibiting Ang II-induced MAPK p44/42 signaling in TGF- $\beta 1$-pretreated RASMC. Previously, it has been demonstrated that TGF- $\beta 1$ could inhibit the epidermal growth factor (EGF) and $\alpha 1 \mathrm{~B}$-adrenergic receptors by modifying their phosphorylation status $[17,18]$. It is, however, unclear whether TGF- $\beta 1$ could have similar effects on $\mathrm{AT}_{1}$ receptors.

Several studies have demonstrated that the hypertrophic effects of Ang II on VSMC in experimental models of diabetes are mediated through the MAPK p44/42 signaling pathway $[2,19]$. In a recent paper by Wang et al. [20], it has been demonstrated that activation of $\mathrm{AT}_{1}$ by Ang II in VSMC results in the activation of the $\operatorname{Smad} 2 / 3$ signaling pathway, a profibrotic pathway that is also activated by TGF- $\beta$. Our study demonstrates for the first time that TGF- $\beta 1$ inhibits the Ang II-mediated MAPK p44/42 signaling pathway. Therefore, the cross-talk between the Ang II and TGF- $\beta 1$ signaling pathways appears to be bidirectional.

We demonstrated that Ang II-mediated proliferation of RASMC could be completely inhibited by pretreatment with TGF- $\beta 1$. This is in line with a previous study demonstrating that Ang II-induced proliferation of human VSMC was mediated through $\mathrm{AT}_{1}$ and MEK [2]. Therefore, the inhibition of Ang II-mediated proliferation of TGF- $\beta 1$-pretreated RASMC is most likely caused by the impaired MAPK p44/42 signaling. Furthermore, it has been demonstrated that TGF- $\beta 1$ could also inhibit EGF-mediated MAPK p44/42 signaling and proliferation of human epithelial cells through inhibition of the EGF receptor [17]. Thus, TGF- $\beta 1$-mediated inhibition of MAPK p44/42 signaling and proliferation appears to apply to multiple receptor systems and cell types.

In contrast to the effect of TGF- $\beta 1$ pretreatment on proliferation, inhibition of MAPK p 44/42 signaling by pretreatment with TGF- $\beta 1$ augmented Ang II-induced PAI-1 expression in RASMC. This is surprising, as several studies have demonstrated that PAI-1 expression is dependent on MEK [8, 21-24]. Possibly, PAI-I expression may be induced through other MAPK routes. It has been demonstrated that both TGF- $\beta 1$ and Ang II can signal through the reactive oxygen species $\mathrm{p} 38 \mathrm{MAP} / \mathrm{JNK}$ route $[25,26]$. Indeed, in fibroblasts, TGF- $\beta 1$-induced PAI- 1 expression is dependent on this pathway [25]. Furthermore, PAI-1 expression may be mediated by HIF- $1 \alpha$ expression through Ang II-mediated stimulation of AT2 receptors [27]. However, the involvement of the p38MAP/ JNK or other pathways in the synergistic upregulation of PAI- 1 by TGF- $\beta 1$ and Ang II in RASMC remains to be established.

The pathophysiological relevance of the inhibitory effect of TGF- $\beta 1$ on MAPK p $44 / 42$ is still unclear. Previous studies have suggested that the balance between vascular fibrosis and vascular proliferation may be controlled by the relative levels of Ang II and TGF- $\beta$ [20, 28]. Indeed, in our study, pretreatment with TGF- $\beta 1$ completely inhibited Ang II-induced proliferation of RASMC, while Ang II and TGF- $\beta 1$ acted synergistically on the increased expression of the early fibrotic marker PAI-1. In recent papers [20,29, 30], a new model has emerged to describe the interaction between $\mathrm{AT}_{1}$ and TGF- $\beta 1$ signaling in vascular remodeling. In these studies, it has been demonstrated that Ang II can directly stimulate the intracellular mediators of TGF- $\beta 1$ signaling, Smad 2 and 3 . This activation of $S \operatorname{mad} 2 / 3$ appears to be bimodal in nature. In the initial phase at $15 \mathrm{~min}$, Ang II directly activates $\operatorname{Smad} 2 / 3$ through $\mathrm{AT}_{1}$ and via MAPK p44/42. In the delayed response to Ang II at $24 \mathrm{~h}$, paracrine production of TGF- $\beta 1$ maintains Smad3 activation, leading to the activation of profibrotic genes. Our current findings suggest that the inhibition of Ang II-mediated MAPK p44/42 signaling by TGF- $\beta 1$ may be part of a negative feedback loop that 
attenuates the direct activation of Smad $2 / 3$ by Ang II and inhibits excessive Ang II-mediated smooth muscle cell proliferation.

In conclusion, in this study we provide the pharmacological characteristics of the TGF- $\beta 1$-induced decrease in Ang II-mediated MAPK signaling in RASMC. We demonstrate that TGF- $\beta 1$ attenuates Ang II-mediated MAPK p44/42 signaling in RASMC through downregulation of $\mathrm{AT}_{1}$ levels, which seems mainly dependent on the inhibition of transcriptional activity of the $\mathrm{AT}_{1}$ gene. Pretreatment with TGF- $\beta 1$ completely inhibited Ang II-mediated proliferation of RASMC, but synergistically increased Ang II-induced PAI-1 expression.

\section{Acknowledgments}

Preliminary data of this study were presented as a poster at the 2007 Annual Meeting of the American Society of Nephrology. These studies were performed with partial support from Dutch Kidney Foundation grant C04.2108 (to L.E.D.) and NIH grant RO1 DK 053867 (to K.S.).

\section{References}

1 Sharma K, Deelman L, Madesh M, Kurz B, Ciccone E, Siva S, Hu T, Zhu Y, Wang L, Henning R, Ma X, Hajnoczky G: Involvement of transforming growth factor-beta in regulation of calcium transients in diabetic vascular smooth muscle cells. Am J Physiol Renal Physiol 2003;285:F1258-F1270.

-2 Touyz RM, Deng LY, He G, Wu XH, Schiffrin EL: Angiotensin II stimulates DNA and protein synthesis in vascular smooth muscle cells from human arteries: role of extracellular signal-regulated kinases. J Hypertens 1999;17:907-916.

$\checkmark 3$ Lee HM, Lee CK, Lee SH, Roh HY, Bae YM, Lee KY, Lim J, Park PJ, Park TK, Lee YL, Won KJ, Kim B: p38 Mitogen-activated protein kinase contributes to angiotensin II-stimulated migration of rat aortic smooth muscle cells. J Pharmacol Sci 2007;105:74-81.

4 Schafer K, Muller K, Hecke A, Mounier E, Goebel J, Loskutoff DJ, Konstantinides S: Enhanced thrombosis in atherosclerosisprone mice is associated with increased arterial expression of plasminogen activator inhibitor-1. Arterioscler Thromb Vasc Biol 2003;23:2097-2103.

5 Eitzman DT, Westrick RJ, Xu Z, Tyson J, Ginsburg D: Plasminogen activator inhibitor-1 deficiency protects against atherosclerosis progression in the mouse carotid artery. Blood 2000;96:4212-4215.

6 Zunker P, Schick A, Padro T, Kienast J, Phillips A, Ringelstein EB: Tissue plasminogen activator and plasminogen activator inhibitor in patients with acute ischemic stroke: relation to stroke etiology. Neurol Res 1999;21: 727-732.

7 Johansson L, Jansson JH, Boman K, Nilsson TK, Stegmayr B, Hallmans G: Tissue plasminogen activator, plasminogen activator inhibitor-1, and tissue plasminogen activator/plasminogen activator inhibitor-1 complex as risk factors for the development of a first stroke. Stroke 2000;31:26-32.
8 Suzuki M, Akimoto K, Hattori Y: Glucose upregulates plasminogen activator inhibitor-1 gene expression in vascular smooth muscle cells. Life Sci 2002;72:59-66.

D9 Yang C, Patel K, Harding P, Sorokin A, Glass WF: Regulation of TGF- $\beta 1 /$ MAPK-mediated PAI-1 gene expression by the actin cytoskeleton in human mesangial cells. Exp Cell Res 2007;313:1240-1250.

10 Kutz SM, Hordines J, McKeown-Longo PJ, Higgins PJ: TGF- $\beta 1$-induced PAI-1 gene expression requires MEK activity and cell-tosubstrate adhesion. J Cell Sci 2001;114:39053914.

11 Park SH, Han HJ: The mechanism of angiotensin II binding downregulation by high glucose in primary renal proximal tubule cells. Am J Physiol Renal Physiol 2002;282: F228-F237.

12 Williams B, Tsai P, Schrier RW: Glucose-induced downregulation of angiotensin II and arginine vasopressin receptors in cultured rat aortic vascular smooth muscle cells: role of protein kinase C. J Clin Invest 1992;90: 1992-1999.

13 Martin MM, Buckenberger JA, Jiang J, Malana GE, Knoell DL, Feldman DS, Elton TS: TGF- $\beta 1$ stimulates human AT1 receptor expression in lung fibroblasts by cross talk between the Smad, p38 MAPK, JNK, and PI3K signaling pathways. Am J Physiol Lung Cell Mol Physiol 2007;293:L790-L799.

14 Hautmann MB, Adam PJ, Owens GK: Similarities and differences in smooth muscle $\alpha$ actin induction by TGF- $\beta$ in smooth muscle versus non-smooth muscle cells. Arterioscler Thromb Vasc Biol 1999;19:2049-2058.

15 Li XC, Zhuo JL: Selective knockdown of AT1 receptors by RNA interference inhibits Val5ANG II endocytosis and NHE-3 expression in immortalized rabbit proximal tubule cells. Am J Physiol Cell Physiol 2007;293: C367-C378.
16 Boulay G, Chretien L, Richard DE, Guillemette G: Short-term desensitization of the angiotensin II receptor of bovine adrenal glomerulosa cells corresponds to a shift from a high- to a low-affinity state. Endocrinology 1994;135:2130-2136.

17 Semlali A, Jacques E, Plante S, Biardel S, Milot J, Laviolette M, Boulet LP, Chakir J: TGF$\beta$ suppresses EGF-induced MAPK signaling and proliferation in asthmatic epithelial cells. Am J Respir Cell Mol Biol 2008;38:202208.

18 Romero-Avila MT, Flores-Jasso CF, GarciaSainz JA: $\alpha 1 B$-adrenergic receptor phosphorylation and desensitization induced by transforming growth factor- $\beta$. Biochem J 2002;368:581-587.

19 Natarajan R, Scott S, Bai W, Yerneni KK, Nadler J: Angiotensin II signaling in vascular smooth muscle cells under high glucose conditions. Hypertension 1999;33:378-384.

20 Wang W, Huang XR, Canlas E, Oka K, Truong LD, Deng C, Bhowmick NA, Ju W, Bottinger EP, Lan HY: Essential role of Smad3 in angiotensin II-induced vascular fibrosis. Circ Res 2006;98:1032-1039.

21 Chen HC, Feener EP: MEK1,2 response element mediates angiotensin II-stimulated plasminogen activator inhibitor-1 promoter activation. Blood 2004; 103:2636-2644.

22 Samarakoon R, Higgins CE, Higgins SP, Kutz SM, Higgins PJ: Plasminogen activator inhibitor type-1 gene expression and induced migration in TGF- $\beta 1$-stimulated smooth muscle cells is pp60(c-src)/MEK-dependent. J Cell Physiol 2005;204:236-246.

-23 Samarakoon R, Higgins PJ: MEK/ERK pathway mediates cell-shape-dependent plasminogen activator inhibitor type 1 gene expression upon drug-induced disruption of the microfilament and microtubule networks. J Cell Sci 2002;115:3093-3103. 
24 Ding L, Xu J, Luo X, Chegini N: Gonadotropin releasing hormone and transforming growth factor $\beta$ activate mitogen-activated protein kinase/extracellularly regulated kinase and differentially regulate fibronectin, type I collagen, and plasminogen activator inhibitor-1 expression in leiomyoma and myometrial smooth muscle cells. J Clin Endocrinol Metab 2004;89:5549-5557.

25 Vayalil PK, Iles KE, Choi J, Yi AK, Postlethwait EM, Liu RM: Glutathione suppresses TGF- $\beta$-induced PAI-1 expression by inhibiting p38 and JNK MAPK and the binding of AP-1, SP-1, and Smad to the PAI-1 promoter. Am J Physiol Lung Cell Mol Physiol 2007;293: L1281-L1292.
26 Baas AS, Berk BC: Differential activation of mitogen-activated protein kinases by $\mathrm{H}_{2} \mathrm{O}_{2}$ and $\mathrm{O}_{2}-$ in vascular smooth muscle cells. Circ Res 1995;77:29-36.

27 Wolf G, Schroeder R, Stahl RA: Angiotensin II induces hypoxia-inducible factor- $1 \alpha$ in PC 12 cells through a posttranscriptional mechanism: role of AT2 receptors. Am J Nephrol 2004;24:415-421.
8 Yokote K, Kobayashi K, Saito Y: The role of Smad3-dependent TGF- $\beta$ signal in vascular response to injury. Trends Cardiovasc Med 2006;16:240-245.

29 Sorescu D: Smad3 mediates angiotensin II- and TGF- $\beta 1$-induced vascular fibrosis: Smad3 thickens the plot. Circ Res 2006;98: 988-989.

30 Rodriguez-Vita J, Sanchez-Lopez E, Esteban V, Ruperez M, Egido J, Ruiz-Ortega M: Angiotensin II activates the Smad pathway in vascular smooth muscle cells by a transforming growth factor- $\beta$-independent mechanism. Circulation 2005;111:2509-2517. 